\title{
EHMTI-0313. Factors influencing stigma towards persons with migraine
}

\author{
RE Shapiro ${ }^{1 *}$, RB Lipton², PB Reiner ${ }^{3}$ \\ From 4th European Headache and Migraine Trust International Congress: EHMTIC 2014 \\ Copenhagen, Denmark. 18-21 September 2014
}

\section{Introduction}

Previously, we demonstrated that stigma towards persons with migraine was comparable in magnitude to stigma towards individuals with epilepsy or panic disorder.

\section{Aim}

We sought to measure stigma towards individuals with differing migraine phenotypes versus comparator conditions.

\section{Methods}

Subjects were recruited on-line (MTurk), consented, and randomized to assess one of six fictional vignettes:

1) a woman with migraine four days/month with zero lost workdays/year (W0)

2) a woman with migraine four days/month with two lost workdays/year (W2)

3) a man with migraine four days/month with two lost workdays/year (M2)

4) a woman with seizures four days/month with two lost workdays/year (E2)

5) a woman caring for her invalid husband four days/ month with two lost workdays/year (H2)

6) a woman with migraine twenty days/month with ten lost workdays/year (W10)

Subjects used sliders from 0 to 100 to answer five questions measuring social distance attitudes (SDA) towards the individual described in the vignette; maximum stigmatizing attitude would be a total SDA score of 500. [Study approved by UBC Office of Research Services.]

\section{Results}

3,617 total US subjects $\geq 19$ years old completed the survey (mean age 33.2 years; $51 \%$ female).

${ }^{1}$ Neurological Sciences, University of Vermont College of Medicine, Burlington, USA

Full list of author information is available at the end of the article
W2/M2/E2 scores and W0/E2 scores did not differ significantly. Relative to W2/M2, W0 was significantly lower and $\mathrm{H} 2$ was significantly higher. W10 was significantly higher than $\mathrm{H} 2$.

\section{Conclusions}

Among MTurk subjects, stigma towards persons with migraine increased with their absenteeism, but did not vary by gender.

No conflict of interest.

\section{Authors' details}

${ }^{1}$ Neurological Sciences, University of Vermont College of Medicine, Burlington, USA. ${ }^{2}$ Neurology, Albert Einstein College Of Medicine, New York, USA. ${ }^{3}$ Psychiatry, University of British Columbia, Vancouver, Canada.

Published: 18 September 2014

doi:10.1186/1129-2377-15-S1-E36

Cite this article as: Shapiro et al:: EHMTI-0313. Factors influencing stigma towards persons with migraine. The Journal of Headache and Pain 2014 15(Suppl 1):E36.

Submit your manuscript to a SpringerOpen ${ }^{\odot}$ journal and benefit from:

- Convenient online submission

- Rigorous peer review

- Immediate publication on acceptance

- Open access: articles freely available online

- High visibility within the field

- Retaining the copyright to your article

Submit your next manuscript at $>$ springeropen.com

\section{SpringerOpen ${ }^{\circ}$}

C 2014 Shapiro et al; licensee Springer. This is an Open Access article distributed under the terms of the Creative Commons Attribution License (http://creativecommons.org/licenses/by/2.0), which permits unrestricted use, distribution, and reproduction in any medium, provided the original work is properly cited. 